\title{
Production and development of porcine tetraploid parthenogenetic embryos
}

\author{
Tao Lin, Jae Eun Lee, Hyeon Yeong Shin, Joo Bin Lee, So Yeon Kim and Dong II Jin* \\ Division of Animal \& Dairy Science, Chungnam National University, Daejeon 34143, Korea
}

\begin{abstract}
The aim of this study was to produce porcine tetraploid $(4 \mathrm{~N})$ parthenogenetic embryos using various methods and evaluate their developmental potential. In method 1 (M1), porcine $4 \mathrm{~N}$ parthenogenetic embryos were obtained by inhibiting extrusion of both first (PB1) and second (PB2) polar bodies; in methods 2 (M2) and 3 (M3), 4N parthenogenetic embryos were obtained by electrofusion of 2-cell stage diploid parthenogenetic embryos derived from inhibition of PB2 or PB1 extrusion, respectively. We found no differences in the rates of cleavage or blastocyst formation or the proportion of $4 \mathrm{~N}$ embryos among M1, M2, and M3 groups. The different methods also did not influence apoptosis rates (number of TUNEL-positive cells/number of total cells) or expression levels of apoptosis-related BAX and BCL2L1 genes. However, total cell and EdU (5-ethynyl-2'-deoxyuridine)-positive cell numbers in $4 \mathrm{~N}$ parthenogenetic blastocysts derived from M1 were higher $(p<0.05)$ than those for M2 and M3 groups. Our results suggest that, although porcine $4 \mathrm{~N}$ parthenogenetic embryos could be produced by a variety of methods, inhibition of PB1 and PB2 extrusion (M1) is superior to electrofusion of 2-cell stage diploid parthenogenetic embryos derived from inhibition of PB2 (M2) or PB1 (M3) extrusion.
\end{abstract}

Keywords: Porcine tetraploid embryo, Parthenogenesis, Polar body, Proliferation

\section{Background}

A tetraploid (4N) embryo complementation strategy has proven to be a useful model for post-implantation development of polyploid cells [1]. The $4 \mathrm{~N}$ cells contribute to extra-embryonic tissues, but rarely contribute to the embryo itself $[2,3]$. In mice and cattle, the birth of chimeric offspring completely derived from embryonic stem (ES) cells or induced pluripotent stem (IPS) cells injected into or aggregated with $4 \mathrm{~N}$ embryos has been reported [4-7]. However, there are apparently no reports of porcine chimeras constructed from ES- or IPS-like cells aggregated with $4 \mathrm{~N}$ embryos. $4 \mathrm{~N}$ embryos are usually produced by electrofusion of two-cellstage embryos [8-10], inhibition of cleavage at an early stage [11], or by inhibition of extrusion of both first and second polar bodies $[1,12,13]$. It has proven to be very difficult to obtain $4 \mathrm{~N}$ embryos through in vitro fertilization (IVF) owing to a high frequency of polyspermic fertilization events [12]. However, in the pig, the ploidy of $4 \mathrm{~N}$ embryos produced using parthenogenetic embryos can more easily be predicted than that of $4 \mathrm{~N}$ embryos obtained using IVF-derived embryos. This study was undertaken to compare the development, quality and ploidy transition of porcine $4 \mathrm{~N}$ parthenogenetic embryos obtained through various methods.

\section{Materials and Methods}

\section{Chemicals and animal ethics statement}

All chemicals and reagents used in current study were purchased from Sigma Corporation (St. Louis, MO, USA), except where indicated. Animal experiments were approved by the Institutional Animal Care and Use Committee of Chungnam National University, Korea.

Received: Jun 26, 2019 Accepted: Jul 2, 2019

"Corresponding author: Dong I1 Jin, Division of Animal \& Dairy Science, Chungnam National University, Daejeon 34143, Korea.

Tel: +82-42-821-5876, E-mail: dijin@cnu.ac.kr

This is an Open Access article distributed under the terms of the Creative Commons Attribution Non-Commercial License (http://creativecommons.org/licenses/by$\mathrm{nc} / 4.0 /$ ) which permits unrestricted non-commercial use, distribution, and reproduction in any medium, provided the original work is properly cited.

Copyright (C) 2019 Korean Society of Animal Science and Technology. 


\section{Oocyte in vitro maturation (IVM)}

Freshly harvested porcine cumulus oocyte complexes (COCs) were rinsed 3-5 times and then cultured in four-well multidishes (50 oocytes/well) in $500 \mu \mathrm{L}$ tissue culture medium (TCM) supplemented with $10 \%$ porcine follicular fluid (PFF), $10 \mathrm{ng} / \mathrm{mL}$ epidermal growth factor (EGF), $10 \mathrm{IU} / \mathrm{mL}$ pregnant mare serum gonadotropin (PMSG), and $10 \mathrm{IU} / \mathrm{mL}$ human chorionic gonadotropin (hCG) for $22 \mathrm{~h}$. COCs were then cultured for an additional $22 \mathrm{~h}$ in the same IVM medium without hormones.

\section{Parthenogenetic activation and in vitro culture}

After a 44-h IVM period, oocytes were freed from follicle cells by treatment with $0.1 \%$ hyaluronidase. Denuded oocytes were washed several times in an activation solution (0.28 M D-mannitol, 0.1 $\mathrm{mM} \mathrm{MgSO}_{4}, 0.05 \mathrm{mM} \mathrm{CaCl}_{2}$, and $0.01 \%$ bovine serum albumin [BSA]), and then activated with a direct current pulse of $1,100 \mathrm{~V} /$ cm for $30 \mu$ s using an Electro Cell Manipulator 2001 (BTX, San Diego, CA, USA). Extrusion of the second polar body was inhibited by immediately culturing activated oocytes in Porcine Zygote Medium-3 (PZM-3) containing $3 \mathrm{mg} / \mathrm{mL}$ BSA plus 0 or $7.5 \mu \mathrm{g} /$ $\mathrm{mL}$ cytochalasin $\mathrm{B}(\mathrm{CB})$ for $3 \mathrm{~h}$, according to experimental requirements. After incubating with $\mathrm{CB}$ for $3 \mathrm{~h}$, presumptive parthenogenetic embryos were transferred into PZM-3 and incubated at $38.5^{\circ} \mathrm{C}$ for $7 \mathrm{~d}$ in a $5 \% \mathrm{CO}_{2}$ atmosphere. The day of activation was designated day 1. Cleavage rate (number of cleaved embryos/number of total tested embryos) and blastocyst formation rate (number of blastocysts/number of total tested embryos) were evaluated on culture days 3 and 7 , respectively.

\section{EdU staining}

Click-iT EdU Imaging Kits (C10337; Invitrogen, Eugene, OR, USA) were used for EdU labeling according to the manufacturer's instructions. Briefly, porcine $4 \mathrm{~N}$ parthenogenetic embryos were cultured in EdU medium $(10 \mu \mathrm{M})$ for $6 \mathrm{~h}$ at $38.5^{\circ} \mathrm{C}$ in a $\mathrm{CO}_{2}$ incubator. Embryos were fixed in 4\% paraformaldehyde for 15 min and then permeabilized with $0.5 \%$ Triton X-100 for 15 min. Embryos were washed in 3\% BSA, and then reacted with Click-
iT reaction cocktail containing Alexa Fluor 488 azide. After EdU staining, samples were stained with 4',6-diamidino-2-phenylindole (DAPI; Vector Laboratories, Inc., Burlingame, CA, USA) and examined under a confocal microscope.

\section{Terminal deoxynucleotidyl transferase-mediated dUTP nick-end labeling (TUNEL) assay}

Blastocyst stage embryos were collected and washed three times in PBS containing $0.1 \%$ polyvinyl alcohol (PBS-PVA). Blastocysts were then fixed and permeabilized with $4 \%$ paraformaldehyde and $0.5 \%$ Triton $\mathrm{X}-100(\mathrm{v} / \mathrm{v})$ for $1 \mathrm{~h}$ at room temperature. After washing several times with PBS-PVA, blastocysts were incubated with TUNEL reaction medium (In Situ Cell Death Detection Kit; TMR red; Roche, Germany) for $1 \mathrm{~h}$ at $38.5^{\circ} \mathrm{C}$ in the dark, and then counterstained with DAPI for $5 \mathrm{~min}$ in the dark to label all blastocyst nuclei. Finally, blastocysts were mounted and imaged under a fluorescence microscope.

\section{Reverse transcription-polymerase chain reaction (RT-PCR)} $4 \mathrm{~N}$ parthenogenetic embryos derived from each experiment group were sampled and stored at $-80^{\circ} \mathrm{C}$ until analysis. Expression levels of the pro-apoptotic gene $B A X$ and anti-apoptotic gene $B C L 2 L 1$ were examined using RT-PCR. Total RNA was isolated from each sample (20 blastocysts) using RNeasy Mini Kits (Qiagen, Valencia, CA, USA; Cat. No. 79254). cDNA was prepared using a TOPscript RT DryMIX kit (Enzynomics, Daejeon, Korea). RT-PCR was performed using an AccuPower PCR PreMix Kit (Bioneer, Daejeon, Korea) according to the manufacturer's instructions. The primer pairs and annealing temperatures for the analyzed genes are listed in Table 1 . The PCR products were separated by electrophoresis on 2\% agarose gels containing EcoDye DNA Staining Solution (Biofact, Korea).

\section{Chromosome counting}

Chromosome analyses of embryos were performed using general procedures described previously, with modifications [13]. Embryos were collected and cultured for $6 \mathrm{~h}$ in PZM-3 medium contain-

Table 1. Primers utilized for gene expression analysis

\begin{tabular}{|c|c|c|c|c|}
\hline Gene & Primer sequence (5'-3') & Accession number & Product size (bp) & Annealing temp $\left({ }^{\circ} \mathrm{C}\right)$ \\
\hline \multirow[t]{2}{*}{$B A X$} & F: ACACCTCATAGCCATGAAAC & YA55048 & 232 & 55 \\
\hline & R: ATGGCTGACATCAAGATACC & & & \\
\hline \multirow[t]{2}{*}{$B C L 2 L 1$} & F: AGAGCTTTGAGCAGGTATTG & NM214285 & 253 & 55 \\
\hline & R: GCATTGTTTCCGTAGAGTTC & & & \\
\hline \multirow[t]{2}{*}{ ACTB } & F: GGTAAGGCTGGGAAGGACTC & U07786 & 326 & 55 \\
\hline & R: CGGTGAGGTACTCCAGGATG & & & \\
\hline
\end{tabular}

$F$, forward; $R$, reverse. 
ing $0.2 \mu \mathrm{g} / \mathrm{mL}$ colcemid, and then transferred to sodium citrate $(0.8 \%,[\mathrm{w} / \mathrm{v}])$ solution for $10-15 \mathrm{~min}$. Individual embryos were then transferred onto glass slides and fixed with a methanol:acetic acid solution (1:1, [v/v]). After each glass slide had dried completely, chromosomes samples were stained with DAPI and coverslip-mounted. Chromosome numbers were determined under a fluorescence microscope.

\section{Experimental design}

\section{Effect of different concentrations of CB on first polar body (PB1) extrusion}

After a 22-h IVM period, oocytes were treated with different concentrations of $\mathrm{CB}(0,1,5,7.5,15 \mu \mathrm{g} / \mathrm{mL})$ for an additional $22 \mathrm{~h}$. Oocytes were denuded completely and examined for the presence of PB1.

\section{Effect of CB on second polar body (PB2) extrusion}

First, PB1 or non-PB1 oocytes were produced according to the needs of the experiment. For production of non-PB1 oocytes (Fig. 1A1-3 or Fig. 1C1-3), oocytes were matured without CB for $22 \mathrm{~h}$, and then cultured with $\mathrm{CB}$ for an additional $22 \mathrm{~h}$ to inhibit PB1 extrusion. For production of PB1 oocytes (Fig. 1B1-3), oocytes were cultured without $\mathrm{CB}$ for $44 \mathrm{~h}$ to allow extrusion of PB1. Second, PB1 oocytes and non-PB1 oocytes were treated with or without $\mathrm{CB}$ for $3 \mathrm{~h}$ after electrical stimulation, and PB2 extrusion was monitored.

\section{Production of diploid (2N) parthenogenetic embryos}

Porcine $2 \mathrm{~N}$ parthenogenetic embryos were obtained by inhibition of PB2 (2N-I-PB2) or PB1 (2N-I-PB1) extrusion. For the 2N-I-PB2 method (Fig. 1B3-5), PB1 oocytes were activated and then treated with $\mathrm{CB}$ for $3 \mathrm{~h}$ to inhibit PB2 extrusion. For the 2N-I-PB1 method (Fig. 1C3-5), non-PB1 oocytes were activated and cultured without $\mathrm{CB}$ to allow PB2 extrusion. Finally, 2N parthenogenetic embryos were cultured in PZM-3 medium, and cleavage and blastocyst formation rates were investigated on culture days 3 and 7, respectively.

\section{Fusion of 2-cell stage $2 \mathrm{~N}$ parthenogenetic embryos}

2-Cell stage $2 \mathrm{~N}$ parthenogenetic embryos derived from $2 \mathrm{~N}-\mathrm{I}-\mathrm{PB} 2$ (Fig. 1B6) or 2N-I-PB1 (Fig. 1C6) groups were pre-equilibrated in fusion solution (same as electro-activation solution), and then

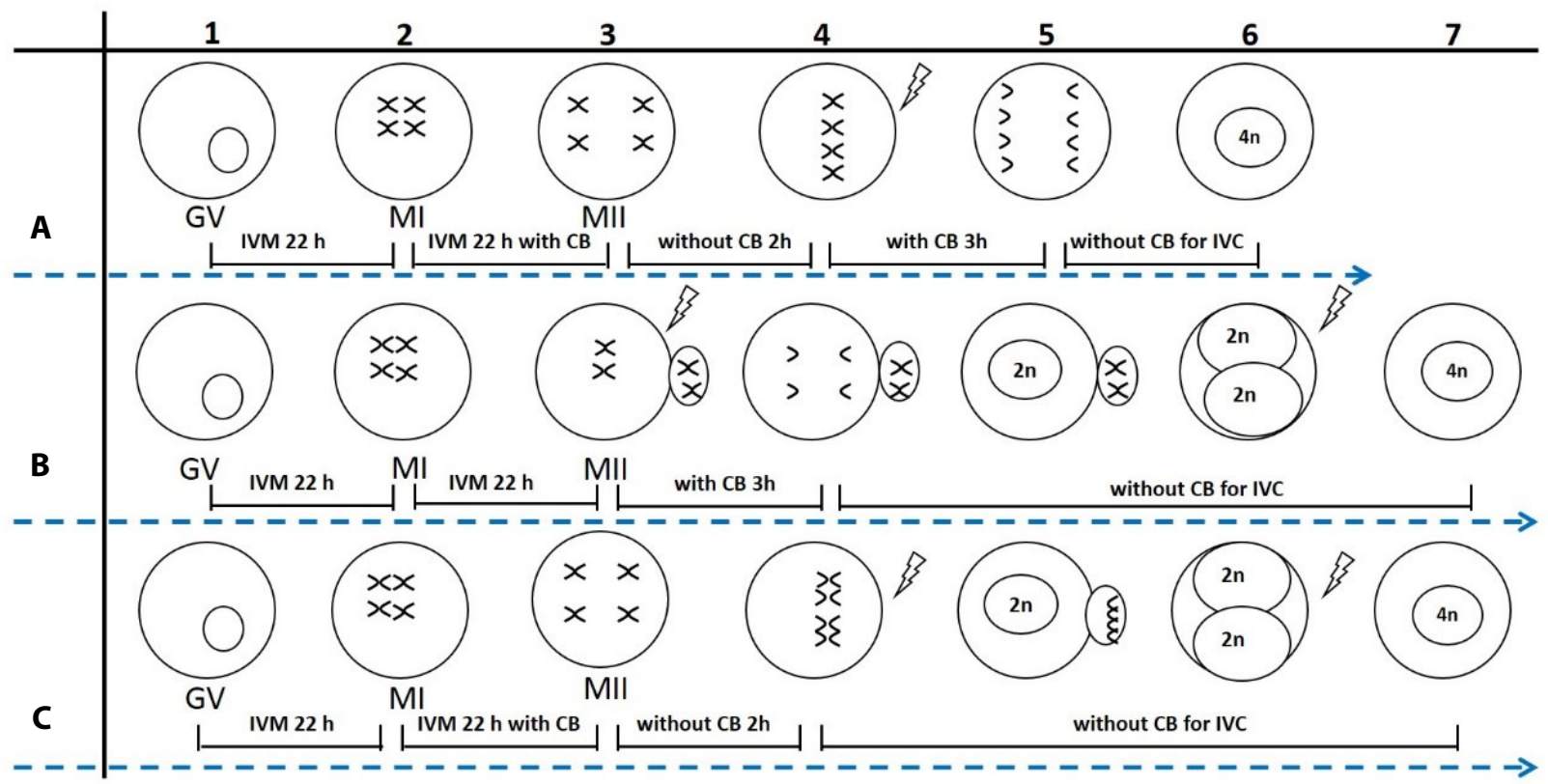

Fig. 1. Schematic depiction of methods for producing $4 \mathrm{~N}$ parthenogenetic embryos in the current study. $A, M 1$, porcine COCs (A1, GV stage) were cultured without $\mathrm{CB}$ for $22 \mathrm{~h}$ (A2, Ml stage), and then cultured with $\mathrm{CB}$ for an additional $22 \mathrm{~h}$ (A3, Mll stage) to inhibit PB1 extrusion (non-PB1 oocytes). Non-PB1 oocytes were cultured in CB-free medium for $2 \mathrm{~h}$, and then subjected to electrical stimulation (A4). After activation, oocytes were again treated with $\mathrm{CB}$ for $3 \mathrm{~h}$ (A5) to inhibit PB2 extrusion; these embryos became $4 \mathrm{~N}$ embryos (A6). B, M2, porcine GV stage oocytes (B1) were cultured for $44 \mathrm{~h}$ (B23) without $\mathrm{CB}$ to allow extrusion of PB1 (PB1 oocytes). After electrical stimulation, embryos were treated with $\mathrm{CB}$ for $3 \mathrm{~h}$ (B4) to inhibit PB2 extrusion; these embryos became $2 \mathrm{~N}$ (B5). About 24-35 h post activation, 2-cell-stage embryos were selected and subjected to electrofusion (B6). Completely fused 2-cell-stage embryos were further cultured to produce $4 \mathrm{~N}$ embryos (B7). C, M3, porcine GV stage oocytes (C1) were cultured without CB for 22 h (C2), and then cultured with $\mathrm{CB}$ for an additional $22 \mathrm{~h}$ (C3) to inhibit PB1 extrusion (non-PB1 embryos). Non-PB1 oocytes were cultured in CB-free medium for $2 \mathrm{~h}$, and then subjected to electrical stimulation (C4). After stimulation, embryos were cultured without CB to allow PB2 extrusion; these embryos became $2 \mathrm{~N}$ (C5). About 24-35 h post activation, 2-cell-stage embryos were selected and subjected to electrofusion (C6). Completely fused 2-cell-stage embryos were further cultured to produce $4 \mathrm{~N}$ embryos (C7). GV, germinal vesicle; MI, metaphase I; MII, metaphase II; COCs, cumulus oocyte complexes; CB, cytochalasin B; PB, polar body. 
embryos in the chamber were aligned with their fusion plane parallel to the two electrodes. Fusion was achieved with a direct current pulse of 1,100 V/cm for $30 \mu$ using an Electro Cell Manipulator. Embryos were observed at $30 \mathrm{~min}$ post electrofusion, and fused embryos were cultured in PZM-3 for further study. 2-Cell embryos derived from $2 \mathrm{~N}-\mathrm{I}-\mathrm{PB} 2$ and $2 \mathrm{~N}-\mathrm{I}-\mathrm{PB} 1$ groups that were not subjected to electrofusion were used as control groups $(\mathrm{C}-2 \mathrm{~N}-$ I-PB2 and C-2N-I-PB1).

\section{Production and development of porcine tetraploid (4N) parthenogenetic embryos}

Porcine $4 \mathrm{~N}$ parthenogenetic embryos were produced by inhibition of both PB1 and PB2 extrusion, termed Method 1 (M1), or by electrofusion of 2-cell stage diploid parthenogenetic embryos derived from 2N-I-PB2 (M2) or 2N-I-PB1 (M3). For M1, nonPB1 oocytes (Fig. 1A3) were activated and then treated with $\mathrm{CB}$ for $3 \mathrm{~h}$ to inhibit PB2 extrusion (Fig. 1A3-6). After treating with $\mathrm{CB}$ for $3 \mathrm{~h}, 4 \mathrm{~N}$ embryos were produced by selecting and culturing non-PB1/non-PB2 embryos in CB-free medium. For M2, completely fused 2-cell stage $2 \mathrm{~N}$ embryos derived from 2N-I-PB2 (Fig. 1B7) were used to produce $4 \mathrm{~N}$ embryos. For $\mathrm{M} 3$, completely fused 2-cell stage $2 \mathrm{~N}$ embryos derived from 2N-I-PB1 (Fig. 1C7) were obtained to produce $4 \mathrm{~N}$ embryos. Finally, $4 \mathrm{~N}$ parthenogenetic embryos from each group were cultured in PZM-3 medium. Cleavage and blastocyst formation rates were investigated on culture days 3 and 7, respectively. Total and EdU-positive cell numbers in blastocysts were also evaluated using EdU labeling.

\section{Apoptosis in $4 \mathrm{~N}$ porcine parthenogenetic embryos}

Apoptotic nuclei in porcine $4 \mathrm{~N}$ parthenogenetic blastocysts were determined by TUNEL assay, and all nuclei were labeled by staining with DAPI. Expression of the apoptosis-related genes $B A X$ and BCL2L1 was analyzed using RT-PCR.

\section{Ploidy of porcine parthenogenetic embryos}

The ploidy of $4 \mathrm{~N}$ parthenogenetic embryos generated by M1, $\mathrm{M} 2$, and M3 was analyzed by subjecting embryos to chromosome counting analysis.

\section{Statistical analysis}

Data were analyzed by one-way analysis of variance (ANOVA) followed by Fisher's protected least significant difference test or $t$-test using SPSS 17.0 software (SPSS Inc., Chicago, IL, USA). Percentage data were subjected to arcsine transformation before analysis. At least three replicates were performed for each experiment, and results are expressed as means \pm standard error (se). $p$-values $<0.05$ were considered significant.

\section{Results}

\section{Effect of different concentrations of CB on PB1 extrusion}

As shown in Fig. 2A, there was no difference in the rate of PB1 extrusion between control and $1 \mu \mathrm{g} / \mathrm{mL} \mathrm{CB}$ groups. However, the rate of $\mathrm{PB} 1$ extrusion significantly decreased with further increases in $\mathrm{CB}$ concentration compared with control and $1 \mu \mathrm{g} / \mathrm{mL}$ groups, plateauing at approximately $7.5 \mu \mathrm{g} / \mathrm{mL}$. Based on these results, we used $7.5 \mu \mathrm{g} / \mathrm{mL} \mathrm{CB}$ for subsequent studies.

\section{Effect of CB on PB2 extrusion}

PB1 embryos and non-PB1 embryos were treated with CB (7.5 $\mu \mathrm{g} / \mathrm{mL}$ ) for $3 \mathrm{~h}$ after electrical stimulation. The rate of $\mathrm{PB} 2$ extrusion was significantly lower with $\mathrm{CB}$ treatment than without $\mathrm{CB}$ treatment in both $\mathrm{PB} 1$ oocytes and non-PB1 oocyte groups (Fig. 2B).

\section{Development of porcine $2 \mathrm{~N}$ parthenogenetic embryos}

There were no differences in the rates of cleavage or blastocyst formation, or total cell numbers in $2 \mathrm{~N}$ parthenogenetic blastocysts

A PB1 extrusion rates

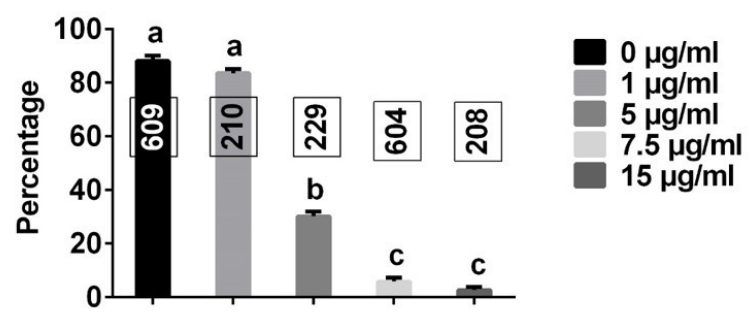

B PB2 extrusion rates

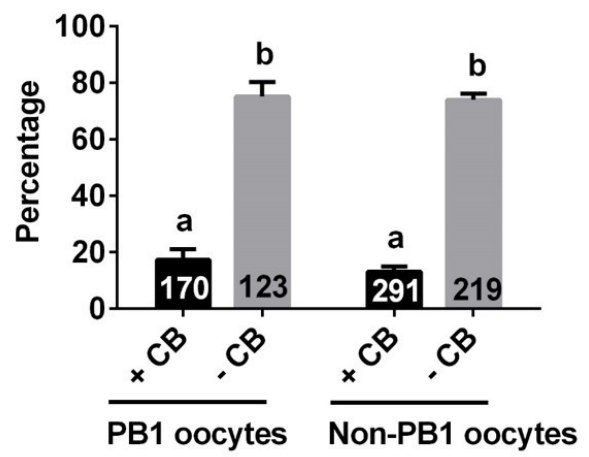

Fig. 2. Effect of $C B$ on extrusion of polar bodies. $A$, Effects of different concentrations $(0,1,5,7.5$, and $15 \mu \mathrm{g} / \mathrm{mL})$ of $C B$ on PB1 extrusion. $B$, Effects of CB $(7.5 \mu \mathrm{g} / \mathrm{mL})$ on PB2 extrusion. The numbers of embryos tested in each group are shown as bars. Different letters indicate significant differences $(p<0.05)$. +CB, with $C B$; $-\mathrm{CB}$, without $\mathrm{CB}$; $\mathrm{CB}$, cytochalasin $\mathrm{B}$; $\mathrm{PB}$, polar body. 
between 2N-I-PB2 and 2N-I-PB1 groups (Fig. 3A, B).

\section{Fusion rates of 2-cell-stage $2 \mathrm{~N}$ embryos}

As shown in Fig. 3C, there were no significant differences in

A
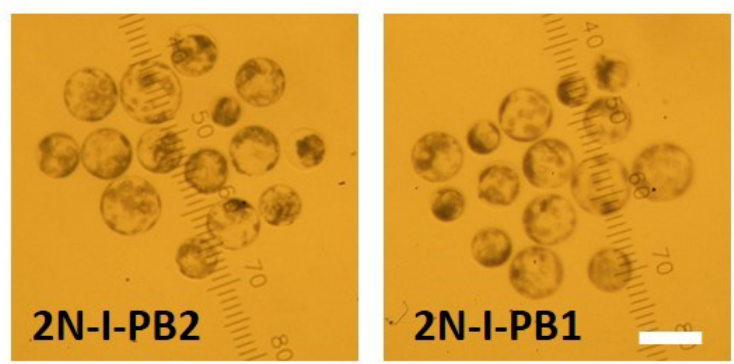

B

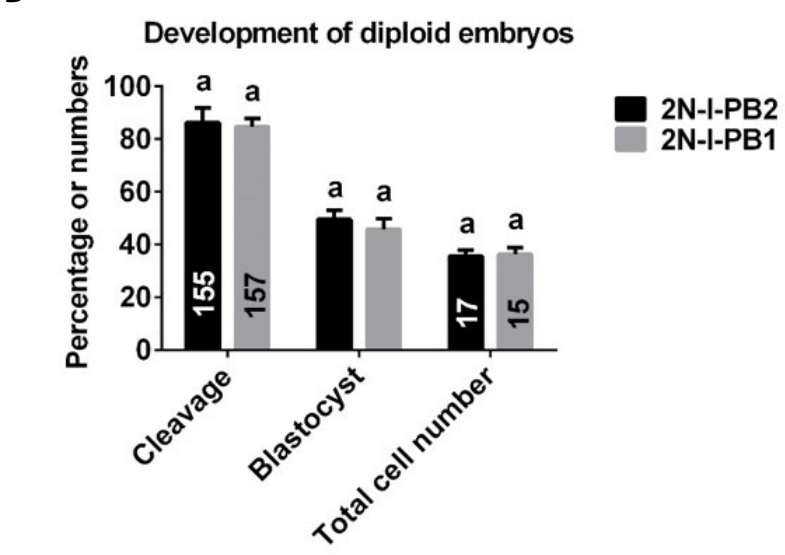

C

Fusion rates of 2-cell stage embryos

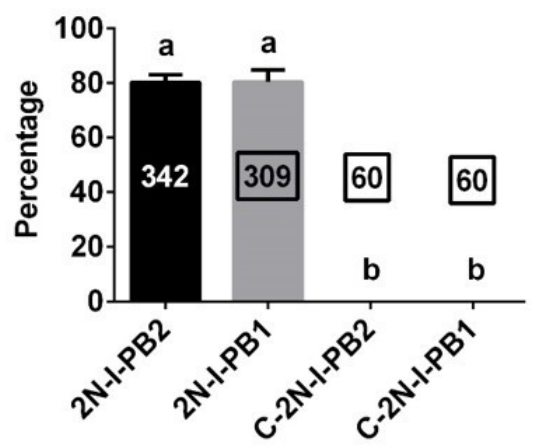

Fig. 3. Development of porcine $2 \mathrm{~N}$ parthenogenetic embryos and fusion rates of 2-cell embryos. A, Images of $2 \mathrm{~N}$ parthenogenetic embryos derived from 2N-I-PB2 and 2N-I-PB1 groups. B, The development of $2 \mathrm{~N}$ parthenogenetic embryos. C, The fusion rates of 2-cell-stage $2 \mathrm{~N}$ embryos. The numbers of embryos tested in each group are shown as bars. Different letters indicate significant differences $(p<0.05)$. Scale bar in A represents $200 \mu \mathrm{m}$. 2N-I-PB2, 2N parthenogenetic embryos produced by inhibition of PB2 extrusion; 2N-I-PB1, 2N parthenogenetic embryos produced by inhibition of PB1 extrusion. 2-Cell-stage $2 \mathrm{~N}$ embryos derived from $2 \mathrm{~N}-\mathrm{I}-$ PB2 and 2N-IPB1 groups not subjected to electrofusion were used as control groups (C-2N-I-PB2 and C-2N-I-PB1). PB, polar body. electrofusion rates between $2 \mathrm{~N}-\mathrm{I}-\mathrm{PB} 2$ and $2 \mathrm{~N}-\mathrm{I}-\mathrm{PB} 1$ groups. As expected, no fusion occurred in C-2N-I-PB2 and C-2N-I-PB1 control groups (Fig. 3C).

\section{Development of porcine $4 \mathrm{~N}$ parthenogenetic embryos}

There were no significant differences in cleavage or blastocyst formation rates among M1, M2, and M3 groups (Fig. 4A, B). How-

A
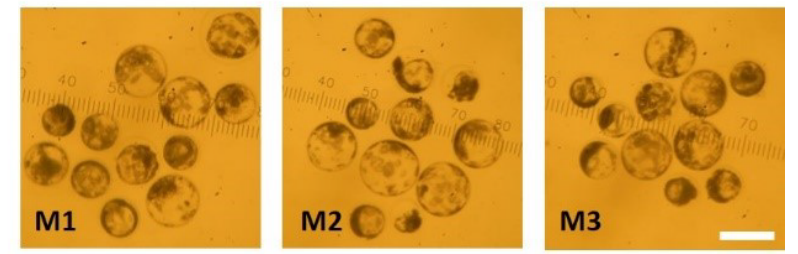

B

Development of $4 \mathrm{~N}$ embryos

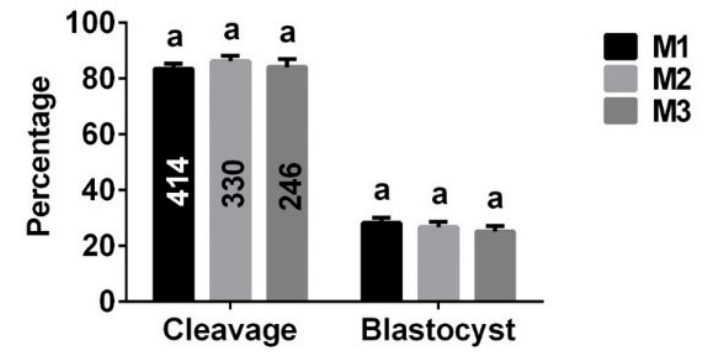

C
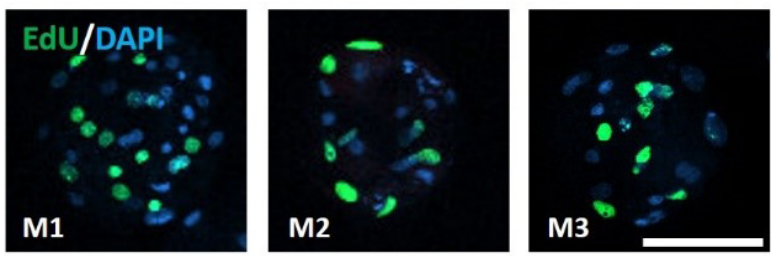

D

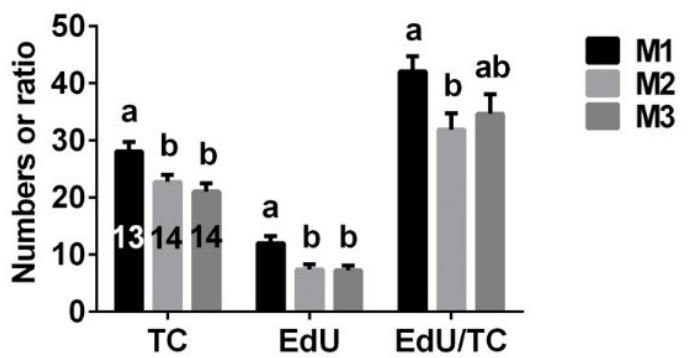

Fig. 4. Development of $4 \mathrm{~N}$ parthenogenetic embryos. A, Images of porcine $4 \mathrm{~N}$ parthenogenetic embryos derived from $\mathrm{M} 1, \mathrm{M} 2$, and $\mathrm{M} 3$ groups. B, Development of $4 \mathrm{~N}$ parthenogenetic embryos. C, Images of $4 \mathrm{~N}$ parthenogenetic blastocysts after EdU staining. Green and blue represent EdU-positive cells and nuclei in blastocysts, respectively. D, Total cell (TC) numbers, EdU-positive cell (EdU) numbers, and ratio of EdU to TC number. The numbers of embryos tested in each group are shown as bars. Different letters indicate significant differences $(p<0.05)$. Scale bars represent 200 $\mu \mathrm{m}$ in $\mathrm{A}$ and $100 \mu \mathrm{m}$ in $\mathrm{C}$. 
ever, total and EdU-positive cell numbers of $4 \mathrm{~N}$ blastocysts were significantly higher in the M1 group than in M2 or M3 groups (Fig. $4 \mathrm{C}, \mathrm{D})$. There was no difference in the ratio of EdU-positive cell numbers to total cell numbers between M2 and M3 groups, but the value of this ratio was significantly lower in the $\mathrm{M} 2$ group than the M1 group (Fig. 4D).

\section{Apoptosis in porcine $4 \mathrm{~N}$ parthenogenetic embryos}

The frequencies of apoptotic cells in blastocysts and embryos were similar in $4 \mathrm{~N}$ blastocysts produced with $\mathrm{M} 1, \mathrm{M} 2$, and M3 (Fig. 5A, B). There were no differences in expression levels of the pro-apoptotic $B A X$ gene or anti-apoptotic $B C L 2 L 1$ gene among embryos derived from M1, M2, and M3 groups (Fig. 5C, D).

\section{Ploidy of porcine parthenogenetic embryos}

The number of chromosome was analyzed after chromosome staining (Fig. 6A). There were no differences in the proportion of 4N embryos among M1, M2, and M3 groups (Fig. 6B).

\section{Discussion}

Here, we compared the effectiveness of a variety of methods for producing porcine $4 \mathrm{~N}$ parthenogenetic embryos. Our results indicated that porcine $4 \mathrm{~N}$ parthenogenetic embryos could be produced using each of the methods tested. However, porcine 4N embryos derived from M1 contained more nuclei than those of embryos derived from M2 or M3, suggesting that M1 is superior to M2 and M3. Because the physiological characteristics of parthenogenetic embryos are similar to those of fertilized embryos, production of parthenogenetic embryos is important in studies of early preimplantation embryo development [14]. Development of parthenogenetic embryos has been extensively evaluated in many
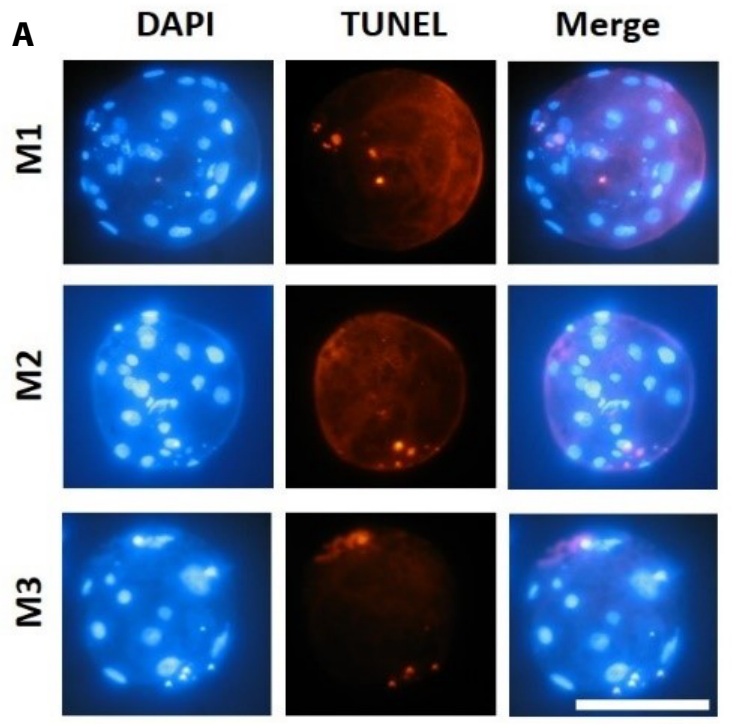

C
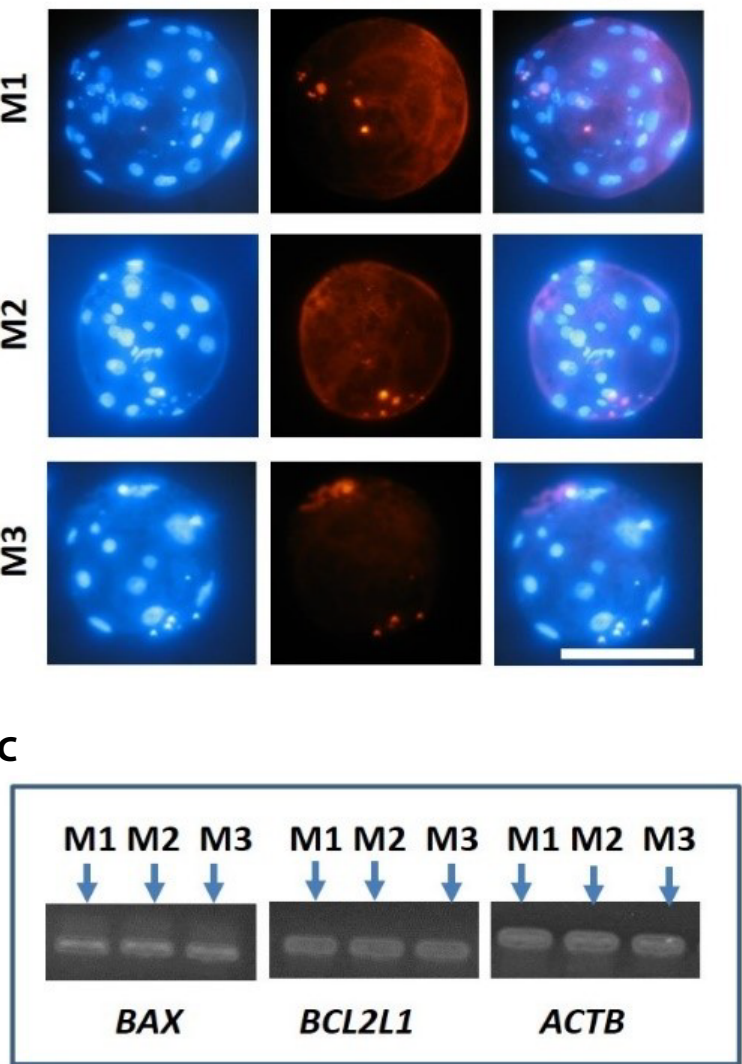

\section{B}

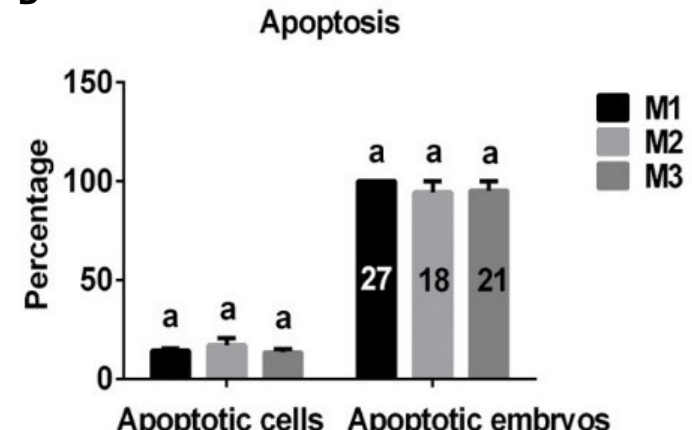

Apoptotic cells Apoptotic embryos

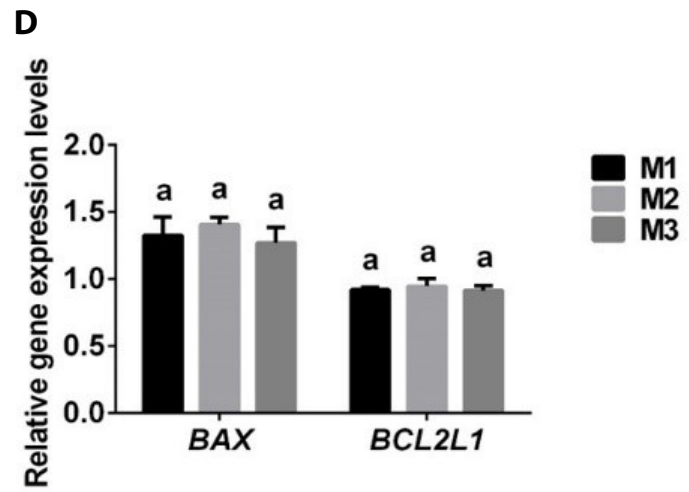

Fig. 5. Apoptosis in porcine $4 \mathrm{~N}$ parthenogenetic embryos. A, Images of apoptosis in porcine $4 \mathrm{~N}$ blastocysts derived from M1, M2, and M3. B, The rates of apoptotic (TUNEL-positive) cells and apoptotic embryos in porcine $4 \mathrm{~N}$ blastocysts. $\mathrm{C}$ and D, Relative expression levels of $B A X$ and $B C L 2 L 1$ genes in porcine $4 \mathrm{~N}$ blastocysts derived from M1, M2, and M3. The numbers of embryos tested in each group are shown as bars. Different letters indicate significant differences $(p<0.05)$. Scale bars in A represent $100 \mu \mathrm{m}$. TUNEL, transferase-mediated dUTP nick-end labeling. 
A
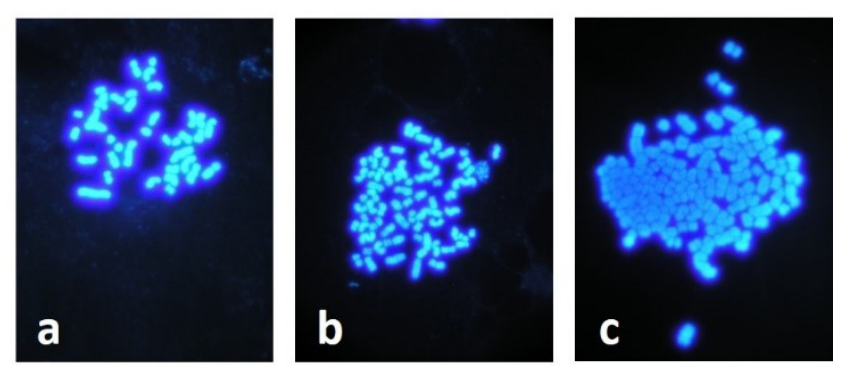

B

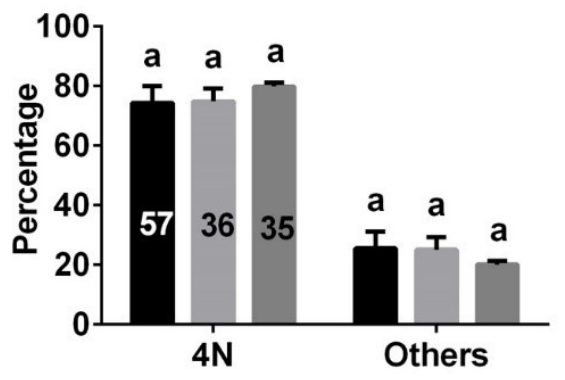

Fig. 6. Ploidy of porcine embryos. A, Chromosome composition of porcine embryos. Aa: diploid $(2 \mathrm{~N}=38)$; Ab: tetraploid $(4 \mathrm{~N}=76)$; Ac: polyploid $(7 \mathrm{~N}=133)$. Magnification: $\times 1,000$. $B$, Proportion of $4 \mathrm{~N}$ embryos derived from M1, M2, and M3 groups; "Others" includes polyploid and mosaic $(2 \mathrm{~N} / 4 \mathrm{~N})$. The numbers of embryos tested in each group are shown as bars. Different letters indicate significant differences $(p<0.05)$.

mammalian species. In general, the developmental competence of $2 \mathrm{~N}$ embryos is more robust than that of haploid $(1 \mathrm{~N})$ or $4 \mathrm{~N} \mathrm{em}-$ bryos $[15,16]$. In the current study, the blastocyst formation rates of $2 \mathrm{~N}$ embryos (Fig. 3B) derived from inhibition of PB2 (2N-IPB2 group) and PB1 (2N-I-PB1 group) extrusion methods were clearly higher than those of $4 \mathrm{~N}$ embryos (Fig. 4B) derived from $\mathrm{M} 1, \mathrm{M} 2$, or M3. Our results are consistent with previous reports that the developmental potential of pig [16] and bovine [1] 4N parthenogenetic embryos is compromised compared with that of $2 \mathrm{~N}$ parthenogenetic embryos. The similarity of both the development and ploidy of porcine $4 \mathrm{~N}$ parthenogenetic embryos derived from M1, M2, and M3 suggests that these methods are equivalent for producing porcine $4 \mathrm{~N}$ parthenogenetic embryos. In the current study, a chromosomal number counting analysis was used to evaluate the ploidy of porcine parthenogenetic embryos. If ploidy of embryos were evaluated using fluorescence in situ hybridization (FISH) analyss [17], the results might be more precise.

The total cell number in blastocysts is a very important parameter for evaluating the quality of embryos [18]. Usually, $2 \mathrm{~N}$ blastocysts have more nuclei than $4 \mathrm{~N}$ embryos [12,16,19]. In the present study, we found that, although the morphology of $4 \mathrm{~N}$ and $2 \mathrm{~N}$ parthenogenetic blastocysts was similar, the total cell number in $4 \mathrm{~N}$ blastocysts (Fig. 4D) was lower than that in $2 \mathrm{~N}$ embryos (Fig. 3B). However, total cell numbers in $4 \mathrm{~N}$ parthenogenetic blastocysts derived from M1 were significantly higher than those from M2 and M3. This result was not surprising since it is known that the $4 \mathrm{~N}$ embryos were produced by blastomere fusion, halting one cell division; thus, $4 \mathrm{~N}$ embryo-derived blastomere fusion methods (M2 and M3) lost one cleavage compared with that of $4 \mathrm{~N}$ embryos derived from inhibition of PB1 and PB2 (M1). In addition, we also found that EdU-positive cell numbers were significantly higher in $4 \mathrm{~N}$ blastocysts derived from the M1 group than the other two groups, indicating that $4 \mathrm{~N}$ parthenogenetic embryos obtained by inhibiting PB1 and PB2 (M1) possess more powerful cell proliferation potential.

In addition to cell numbers, apoptosis is another important indicator of embryo quality $[20,21]$. Using TUNEL assays and RT$\mathrm{PCR}$ analyses to assess apoptosis in porcine $4 \mathrm{~N}$ parthenogenetic embryos, we found no differences in apoptosis rate (TUNEL-positive cells/total cells) or expression levels of the anti-apoptotic $B C L 2 L 1$ gene or pro-apoptotic $B A X$ gene among blastocysts produced from M1, M2, and M3, suggesting that apoptosis was not influenced by the different $4 \mathrm{~N}$ parthenogenetic embryo-generation methods.

In conclusion, we report the production of porcine $4 \mathrm{~N}$ parthenogenetic embryos by inhibition of both PB1 and PB2 (M1), or electrofusion of 2-cell stage $2 \mathrm{~N}$ parthenogenetic embryos derived from inhibition of PB2 (M2) or PB1 (M3) extrusion. Total and EdU-positive cell numbers in $4 \mathrm{~N}$ parthenogenetic embryos derived from the M1 group were significantly higher than those from M2 and M3 groups, although in each case embryos had similar developmental potential and $4 \mathrm{~N}$ ploidy proportion. Different methods also did not change apoptosis rates in $4 \mathrm{~N}$ parthenogenetic embryos. Our study provides an efficient approach for producing $4 \mathrm{~N}$ parthenogenetic embryos, and establishes reference values for the production and development of porcine $4 \mathrm{~N}$ parthenogenetic embryos.

\section{Competing interests}

No potential conflict of interest relevant to this article was reported.

\section{Funding sources}

This work was supported by the National Research Foundation of Korea (NRF) grant funded by the Korea government (MEST) (NRF-2019R1I1A3A01061877).

\section{Acknowledgements}

Not applicable.

\section{Availability of data and material}

Upon reasonable request, the datasets of this study can be available 
from the corresponding author.

\section{Authors' contributions}

Conceptualization: Jin DI.

Data curation: Lin T, Lee JE.

Formal analysis: $\mathrm{Lin} \mathrm{T}$.

Methodology: Shin HY, Kim SY.

Validation: Shin HY, Kim SY.

Investigation: Jin DI.

Writing - original draft: Lin T, Jin DI.

Writing - review \& editing: Lin T, Lee JE, Shin HY, Lee JB, Kim SY, Jin DI.

\section{Ethics approval and consent to participate}

Animal experiments were approved by the Institutional Animal Care and Use Committee of Chung Nam National University, Korea.

\section{ORCID}

Tao Lin

Jae Eun Lee

Hyeon Yeong Shin

Joo Bin Lee

So Yeon Kim

Dong Il Jin

https://orcid.org/0000-0001-9100-6042

https://orcid.org/0000-0003-1435-5980

https://orcid.org/0000-0003-4248-7331

https://orcid.org/0000-0002-6106-9082

https://orcid.org/0000-0001-8080-3126

https://orcid.org/0000-0001-6586-4393

\section{References}

1. Bai C, Liu H, Liu Y, Wu X, Cheng L, Bou S, et al. Diploid oocyte formation and tetraploid embryo development induced by cytochalasin B in bovine. Cell Reprogram. 2011;13:37-45.

2. Lin J, Shi L, Zhang M, Yang H, Qin Y, Zhang J, et al. Defects in trophoblast cell lineage account for the impaired in vivo development of cloned embryos generated by somatic nuclear transfer. Cell Stem Cell. 2011;8:371-5.

3. Okada Y, Ueshin Y, Isotani A, Saito-Fujita T, Nakashima H, Kimura K, et al. Complementation of placental defects and embryonic lethality by trophoblast-specific lentiviral gene transfer. Nat Biotechnol. 2007;25:233-7.

4. Iwasaki S, Campbell KH, Galli C, Akiyama K. Production of live calves derived from embryonic stem-like cells aggregated with tetraploid embryos. Biol Reprod. 2000;62:470-5.

5. Kang L, Wang J, Zhang Y, Kou Z, Gao S. iPS cells can support full-term development of tetraploid blastocyst-complemented embryos. Cell Stem Cell. 2009;5:135-8.

6. Zhao XY, Li W, Lv Z, Liu L, Tong M, Hai T, et al. iPS cells produce viable mice through tetraploid complementation. $\mathrm{Na}^{-}$ ture. 2009;461:86-90.
7. Nagy A, Gocza E, Diaz EM, Prideaux VR, Ivanyi E, Markkula M, et al. Embryonic stem cells alone are able to support fetal development in the mouse. Development. 1990;110:815-21.

8. Krivokharchenko A, Galat V, Ganten D, Bader M. In vitro formation of tetraploid rat blastocysts after fusion of two-cell embryos. Mol Reprod Dev. 2002;61:460-5.

9. Hiriart MI, Bevacqua RJ, Canel NG, Fernandez-Martin R, Salamone DF. Production of chimeric embryos by aggregation of bovine egfp eight-cell stage blastomeres with two-cell fused and asynchronic embryos. Theriogenology. 2013;80:357-64.

10. He W, Kong Q, Shi Y, Xie B, Jiao M, Huang T, et al. Generation and developmental characteristics of porcine tetraploid embryos and tetraploid/diploid chimeric embryos. Genom Proteom Bioinform. 2013;11:327-33.

11. Snow MH. Tetraploid mouse embryos produced by cytochalasin B during cleavage. Nature. 1973;244:513-5.

12. Sembon S, Fuchimoto D, Iwamoto M, Suzuki S, Yoshioka K, Onishi A. A simple method for producing tetraploid porcine parthenogenetic embryos. Theriogenology. 2011;76:598-606.

13. Lin T, Diao YF, Kang JW, Lee JE, Kim DK, Jin DI. Chromosomes in the porcine first polar body possess competence of second meiotic division within enucleated MII stage oocytes. Plos One. 2013;8:e82766.

14. Paffoni A, Brevini TA, Gandolfi F, Ragni G. Parthenogenetic activation: biology and applications in the ART laboratory. Placenta. 2008;29 Suppl: 121-5.

15. Kim NH, Uhm SJ, Ju JY, Lee HT, Chung KS. Blastocoele formation and cell allocation to the inner cesll mass and trophectoderm in haploid and diploid pig parthenotes developing in vitro. Zygote. 1997;5:365-70.

16. Somfai T, Ozawa M, Noguchi J, Kaneko H, Ohnuma K, Karja NW, et al. Diploid porcine parthenotes produced by inhibition of first polar body extrusion during in vitro maturation of follicular oocytes. Reproduction. 2006;132:559-70.

17. Kawarasaki T, Matsumoto K, Chikyu M, Itagaki Y, Horiuchi A. Sexing of porcine embryo by in situ hybridization using chromosome Y- and 1-specific DNA probes. Theriogenology. 2000;53:1501-9.

18. Lin T, Lee JE, Oqani RK, Kim SY, Cho ES, Jeong YD, et al. Delayed blastocyst formation or an extra day culture increases apoptosis in pig blastocysts. Anim Reprod Sci. 2017;185:12839.

19. Koizumi N, Fukuta K. Preimplantation development of tetraploid mouse embryo produced by cytochalasin B. Exp Anim. 1995;44:105-9.

20. Lin T, Diao YF, Choi HS, Oqani RK, Kang JW, Lee JE, et al. Procedure used for denuding pig oocytes influences oocyte damage, and development of in vitro and nuclear transfer em- 
bryos. Anim Reprod Sci. 2015;152:65-76.

21. Hao YH, Lai L, Mao J, Im GS, Bonk A, Prather RS. Apoptosis and in vitro development of preimplantation porcine embryos derived in vitro or by nuclear transfer. Biol Reprod. 2003;69:501-7. 